\title{
SINERGISME INOKULASI Bradyrhizobium japonicum DAN MIKROBA PELARUT FOSFAT TERHADAP PERTUMBUHAN DAN HASIL TANAMAN KEDELAI
}

\author{
SYNERGYSM OF Bradyrhizobium japonicum INOCULANT AND PHOSPHATE \\ MICROBIALS SOLVENT ON SOYBEAN GROWTH AND PRODUCTION
}

\author{
SYARULLAH SALMAN DAN UMAR DANI* \\ Dosen Program Agroteknologi Faperta Universitas Majalengka \\ *e-mail: umardani@unma.ac.id
}

\begin{abstract}
ASTRACT
This study aimed to analyze the synergism between Bradyrhizobium japonicum inoculant with phosphate microbials solvent, and to measure the optimum dose for soybean growth and production. The experiment was conducted at the Agricultural Counseling Center of Majalengka District, West Java from March to June 2021. The design used in this experiment was a Randomized Block Design (RBD) with a $2 x 2$ factorial arangement. The first factor was the dose of B. japonicum inoculant $(R)$ and the second factor was the dose of Phosphate Microbials solvent $(P)$. The results showed that synergistically inoculation of B. japonicum at a dose of $5 \mathrm{~g} \mathrm{~kg}^{-1}$ seeds and phosphate microbials solvent $50 \mathrm{~kg} \mathrm{ha}^{-1}$ could increase the number of effective nodules by $110.48 \%$ and root loss ratio by $13.83 \%$. Inoculation dose of B. japonicum $5 \mathrm{~g} \mathrm{kg-1} \mathrm{seed} \mathrm{reduced} \mathrm{the} \mathrm{number} \mathrm{of} \mathrm{ineffective}$ nodules by $46.54 \%$, increased the effective nodule diameter by $1.75 \%$, increased leaf area index by $14.69 \%$, increased the number of pods by $16.04 \%$, decreased the number of empty pods by $3.62 \%$, increased the weight of pods per plant by $17.20 \%$, increased the weight of 100 seeds by $1.55 \%$, increased the weight of seeds per plant by $17.20 \%$, and increased the weight of seeds per plot by $16.99 \%$. A dose of $150 \mathrm{~kg} \mathrm{ha-1}$ can increase the effective nodule diameter up to $0.98 \%$, reducing the number of empty pods by $29.82 \%$. It can be concluded that the interaction between B. japonicum inoculation with phosphate microbials solvent, and a dose of $150 \mathrm{~kg} \mathrm{ha}^{-1}$ was to get the better growth and yields.
\end{abstract}

Key words: Soybean Growth and Production, Bradyrhizobium japonicum, Phosphate Microbials Solvent

\begin{abstract}
ABSTRAK
Penelitian ini bertujuan untuk menganalisis sinergisme antara inokulasi B japonicum dan mikroba dan pelarut fosfat dan dosis optimum pada pertumbuhan dan hasil tanaman kedelai. Percobaan dilakukan di lahan Balai Penyuluhan Pertanian (BPP) Kecamatan Majalengka Kabupaten Majalengka Jawa Barat pada bulan Maret sampai dengan Juni 2021. Rancangan yang digunakan dalam Percobaan ini adalah Rancangan Acak Kelompok (RAK) dengan Pola Faktorial 2x2. Faktor pertama dosis inokulan B. japonicum (R) dan faktor kedua dosis Mikroba Pelarut Fosfat (P). Hasil penelitian menunjukkan bahwa Secara sinergis Inokulasi B. japonicum pada dosis $5 \mathrm{~g} \mathrm{~kg}^{-1}$ benih dan mikroba pelarut fosfat $50 \mathrm{~kg} \mathrm{ha}^{-1}$ dapat meningkatkan jumlah nodula efektif sebesar $110,48 \%$ dan nisbah pupus akar sebesar 13,83\%. Dosis Inokulasi B. japonicum $5 \mathrm{~g} \mathrm{~kg}^{-1} \mathrm{benih}$ menurunkan jumlah nodula tidak efektif sebesar 46,54\%, meningkatkan diameter nodula efektif sebesar 1,75\%, meningkatkan indek luas daun sebesar 14,69\%, meningkatkan jumlah polong sebesar 16,04\%, menurunkan jumlah polong hampa sebesar 3,62\%, meningkatkan bobot polong per tanaman sebesar 17,20\%, meningkatkan bobot 100 biji sebesar $1,55 \%$, meningkatkan bobot biji per tanaman sebesar 17,20\%, dan meningkatkan bobot bibi per petak sebesar $16,99 \%$. Dosis $150 \mathrm{~kg} \mathrm{ha}^{-1}$ dapat meningkatkan diameter nodula efektif hingga $0,98 \%$, menurunkan jumlah polong hampa 29,82\%. Dapat disimpulkan bahwa adanya interaksi antara inokulasi B. japonicum dengan mikroba pelarut phospate, dan dosis $150 \mathrm{~kg} \mathrm{ha}^{-1}$ mampu menghasilkan pertumbuhan dan hasil yang lebih baik.
\end{abstract}

Kata Kunci : Kedelai, Pertumbuhan, Hasil, Bradyrhizobium japonicum, Mikroba Pelarut Fosfat

\section{PENDAHULUAN}

Kedelai (Glycine $\max$ (L.) Merril) adalah komoditas pangan utama yang secara luas sebagai bahan pangan sumber protein nabati yang murah. Kebutuhan kedelai nasional tidak diimbangi oleh peningkatan areal panen, produksi dan produktivitas. Produktivitas kedelai nasional pada tahun 2015 - 2020 cenderung mengalami peningkatan, namun masih termasuk rendah dibandingkan potensi hasil. Produktivitas yang cendrung meningkat, karena kontribusi sistem 
intensifikasi pertanian yang bertumpu pada penggunaan input eksternal, terutama pupuk nitrogen $(\mathrm{N})$ dan Fosfat $(\mathrm{P})$.

Efisensi penggunaan pupuk $\mathrm{N}$ tergolong rendah karena hanya 33\% yang diserap oleh tanaman (Raun dan Johnson, 1999) dan sebagian besar $63 \%$ hilang melalui proses pencucian, denitrifikasi, mobilisasi dan volatisasi (Nielsen, 2006). Penggunaan pupuk fosfat (P) juga memiliki nilai efisensi yang tergolong. Pupuk fosfat di dalam tanah mengalami reaksi pengendapan yang sangat reaktif dengan $\mathrm{Ca}^{2+}, \mathrm{Mg}^{2+}, \mathrm{Fe}^{3+}$ dan $\mathrm{Al}^{3+}$ (Singh dan Purohit, 2011) dan imobilisasi menjadi komplek organik oleh jasad renik, sehingga $\mathrm{P}$ tidak tersedia bagi tanaman. Hal ini yang menyebakan efisiensi penggunaan pupuk fosfat menjadi sangat rendah antara 10$25 \%$ (Isherword, 1998). Hanya 10-25\% pupuk $\mathrm{P}$ yang diaplikasikan diserap oleh tanaman, selebihnya $90-75 \%$ dalam bentuk P tidak larut.

Biji kedelai yang berkualitas tinggi dan kaya protein sangat ditentukan oleh ketersediaan $\mathrm{N}$ dan $\mathrm{P}$ secara optimal di dalam tanah (Vance, 2001). Penggunaan input eksternal berupa pupuk nitrogen (N) dan Fosfat $(\mathrm{P})$ yang terus meningkat sangat tidak efisien dang sangat berdampak negatif terhadap ekosistem pertanian. Sementara, tanaman kedelai secara alami mempunyai potensi adaptif dengan keterbatasan $\mathrm{N}$ dan $\mathrm{P}$ di dalam tanah melalui asosiasi simbiosis dengan rhizobia fiksasi $\mathrm{N}_{2}$ dan asosiasi non simbiosis dengan mikoriza dan/atau mikroba pelarut fosfat (Vance, 2001), sehingga kebutuhan unsur $\mathrm{N}$ dan $\mathrm{P}$ tetap tersedia bagi tanaman kedelai walaupun dalam keadaan $\mathrm{N}$ dan $P$ yang terbatas di dalam tanah.

Pemahaman mengenai potensi adaptif ini dapat dijadikan acuan untuk menentukan teknologi alternatif pilihan yang lebih efisien, efektif dan berkelanjutan. Teknologi pilihan yang strategis adalah pendekatan yang mensinergiskan interaksi antara tanaman dengan mikroba yang berperan mengatur ketersediaan hara bagi tanaman. Teknologi yang dapat dikembangkan adalah inokulasi Bradyrhizobium japonicum (B. japonicum) dan Mikroba Pelarut Fosfat. Inokulasi $B$. japonicum dan Mikroba Pelarut Fosfat diharapkan dapat meningkatkan pertumbuhan dan hasil kedelai. Penelitian Zarei et al. (2011) melaporkan bahwa pemupukan $\mathrm{P}$ disertai inokulasi B. japonicum dan bakteri pelarut fosfat meningkatkan indeks luas daun, bobot kering tanaman, jumlah polong per tanaman, jumlah biji per polong, jumlah biji per tanaman, bobot 100 biji, dan bobot biji tanaman kedelai. Efisiensi inokulasi $B$. japonicum dan pupuk fostat disertai inokulasi bakteri pelarut fosfat terbukti lebih tinggi (50\%) dibandingkan perlakuan konvensional (Wasule, 2008). Penelitian ini bertujuan meningkatkan pertumbuhan dan hasil tanaman kedelai dengan input produksi yang lebih murah, efisien dan ramah lingkungan.

\section{METODE PENELITIAN}

Penelitian ini merupakan percobaan lapangan yang dilaksanakan di lahan Balai Penyuluhan Pertanian (BPP) Kecamatan/ Kabupaten Majalengka Propinsi Jawa Barat pada bulan Maret sampai Juni 2021. Lokasi percobaan terletak pada ketinggian $220 \mathrm{~m} \mathrm{dpl}$ dengan tipe agroklimat D2 (Oldeman,1982) dan jenis tanah Oxisol dengan pH 6,8 (Netral). Bahan yang digunakan adalah benih kedelai kultivar Anjasmoro sebagai tanaman model, Inokulan B. japonicum dan Mikroba Pelarut Fosfat. Pengadaan Isolat bakteri fiksasi N ( $B$. japonicum), bakteri pelarut fosfat (BPF) (Bacillus sp. dan $P$. fluorescens) dan jamur pelarut fosfat (JPF) (A. niger) diperoleh dari Laboratorium Mikrobiologi Fakultas Pertanian UNPAD. Sarana produksi lainnya yang digunakan adalah batuan fosfat, pupuk Urea, $\mathrm{KCl}$, insektisida dan fungisida. Peralatan yang digunakan adalah cangkul, tugal, kored, tali, karung plastik dan peralatan penunjang lainnya. Selain itu digunakan beberapa peralatan pengamatan di lapangan, dokumentasi foto, timbangan digital dan komputer. Rancangan yang digunakan dalam Percobaan ini adalah Rancangan Acak Kelompok (RAK) dengan Pola Faktorial. Faktor pertama dosis inokulan pupuk hayati (B. japonicum) (R) dan faktor kedua dosis Mikroba Pelarut Fosfat (B). Variabel respons terdiri dari pengamatan komponen pertumbuhan (Jumlah Nodula Efekif, Jumlah Nodula tidak Efekif, Ukuran Nodula Efekif, Nisbah Pupus Akar (P/A), Indeks luas daun, Laju Tumbuh Tanaman, dan Laju Asimilasi Bersih), pengamatan Komponen Hasil dan Hasil (Jumlah polong isi, Jumlah polong hampa, Bobot polong, Bobot per 100 biji, Bobot biji per tanaman, Bobot Biji per Petak), dan Pengamatan Efisiensi Penggunaan Pupuk 
Inokulan Pupuk Hayati (B. japonicum) dan Mikroba Pelarut Fosfat.

\author{
HASIL DAN PEMBAHASAN \\ Hasil \\ Jumlah Nodula Efektif,
}

Hasil analisis ragam menunjukkan terdapat pengaruh interaksi secara sinergis antara inokulasi pupuk hayati (B. japonicum) dan mikroba pelarut fosfat terhadap jumlah nodula efektif. Perbandingan antar rata-rata perlakuan dilakukan dengan menggunakan $\mathrm{Uji}$ Jarak Berganda Duncan pada taraf nyata 5\%, dan hasil analisis dapat dilihat pada Tabel 1.

Tabel 1. Pengaruh Pemberian Inokulan Pupuk Hayati (B. japonicum) dan Bio-fosfat terhadap Jumlah Nodula Efektif.

\begin{tabular}{ccccc}
\hline Inokulan & \multicolumn{4}{c}{ Mikroba Pelarut Fosfat } \\
\cline { 2 - 5 } B. japonicum & $0 \mathrm{~kg} \mathrm{ha}^{-1}$ & $50 \mathrm{~kg} \mathrm{ha}^{-1}$ & $100 \mathrm{~kg} \mathrm{ha}^{-1}$ & $150 \mathrm{~kg} \mathrm{ha}^{-1}$ \\
\hline $0 \mathrm{~g} \mathrm{~kg}^{-1}$ benih & $22.52 \mathrm{a}$ & $32.53 \mathrm{a}$ & $41.39 \mathrm{a}$ & $31.82 \mathrm{a}$ \\
& $\mathrm{A}$ & $\mathrm{AB}$ & $\mathrm{B}$ & $\mathrm{AB}$ \\
$5 \mathrm{~g} \mathrm{~kg}^{-1}$ benih & $42.84 \mathrm{~b}$ & $47.40 \mathrm{~b}$ & $39.55 \mathrm{a}$ & $33.42 \mathrm{a}$ \\
& $\mathrm{AB}$ & $\mathrm{B}$ & $\mathrm{AB}$ & $\mathrm{A}$ \\
$10 \mathrm{~g} \mathrm{~kg}^{1}$ benih & $39.56 \mathrm{~b}$ & $45.86 \mathrm{~b}$ & $39.73 \mathrm{a}$ & $41.63 \mathrm{ab}$ \\
& $\mathrm{A}$ & $\mathrm{A}$ & $\mathrm{A}$ & $\mathrm{A}$ \\
$15 \mathrm{~g} \mathrm{~kg}^{-1}$ benih & $43.52 \mathrm{~b}$ & $44.04 \mathrm{~b}$ & $45.62 \mathrm{a}$ & $44.88 \mathrm{~b}$ \\
& $\mathrm{~A}$ & $\mathrm{~A}$ & $\mathrm{~A}$ & $\mathrm{~A}$ \\
\hline
\end{tabular}

Keterangan: Nilai rata-rata yang ditandai huruf kecil yang sama (arah vertikal) dan huruf kapital yang sama (arah horizontal) tidak berbeda nyata menurut Uji Jarak Berganda Duncan $5 \%$.

Tabel 1. menunjukan bahwa interaksi inokulasi B. japonicum dan mikroba pelarut fosfat secara sinergis mampu meningkatkan jumlah nodula epektif. Inokulasi B. japonicum dengan dosis $5 \mathrm{~g} \mathrm{~kg}^{-1}$ benih dan mikroba pelarut fosfat $50 \mathrm{~kg} \mathrm{ha}^{-1}$ dapat meningkatkan jumlah nodula efektif dibanding dosis inokulasi B. japonicum dengan dosis $0 \mathrm{~g} \mathrm{~kg}^{-1}$ benih dan mikroba pelarut fosfat $0 \mathrm{~kg} \mathrm{ha}^{-1}$.

\section{Jumlah Nodula Tidak Efektif, dan Diameter Nodula Efektif}

Hasil analisis ragam menunjukkan tidak terdapat pengaruh interaksi secara sinergis antara inokulasi pupuk hayati (B. japonicum) dan mikroba pelarut fosfat terhadap jumlah nodula tidak efektif dan diameter nodula efektif $\quad(p<0.05)$. Inokulasi $B$. japonicum secara mandiri menunjukkan terdapat pengaruh nyata terhadap jumlah nodula tidak efektif dan diameter nodula efektif. Inokulasi mikroba pelarut fosfat secara mandiri menunjukkan tidak terdapat pengaruh nyata terhadap jumlah nodula tidak efektif, tetapi menunjukkan pengaruh nyata terhadap diameter nodula efektif. Perbandingan antar rata-rata perlakuan dilakukan dengan menggunakan Uji Jarak Berganda Duncan pada taraf nyata $5 \%$ dan hasil analisis dapat dilihat pada Tabel 2.

Tabel 2 menunjukkan bahwa inokulasi B. japonicum pada dosis $5 \mathrm{~g} \mathrm{~kg}^{1}$ benih dapat menurunkan jumlah nodula tidak efektif, tetapi pada dosis yang lebih tinggi menunjukkan tidak terdapat perbedaan dibanding dosis $0 \mathrm{~g} \mathrm{~kg}^{1}$ benih. Inokulasi $B$. Japonicum pada $5 \mathrm{~g} \mathrm{~kg}^{1}$ benih hingga $15 \mathrm{~g} \mathrm{~kg}^{1}$ benih dapat meningkatkan diameter nodula efektif dibanding dosis $0 \mathrm{~g} \mathrm{~kg}^{1}$ benih.

Inokulasi mikroba pelarut fosfat pada dosis $50 \mathrm{~kg} \mathrm{ha}^{-1}$ hingga $150 \mathrm{~kg} \mathrm{ha}^{-1}$ tidak menurunkan jumlah nodula efektif, tetapi pada dosis $50 \mathrm{~kg} \mathrm{ha}^{-1}$ hingga $150 \mathrm{~kg} \mathrm{ha}^{-1}$ dapat meningkatkan meningkatkan diameter nodula efektif dibanding dosis $0 \mathrm{~g} \mathrm{~kg}^{1}$ benih. 
Tabel 2. Pengaruh Pemberian Inokulan Pupuk Hayati (B. japonicum) dan Bio-fosfat terhadap Jumlah Nodula Inefektif dan Ukuran Nodula Efektif.

\begin{tabular}{|c|c|c|}
\hline Perlakuan & $\begin{array}{l}\text { Jumlah } \\
\text { Nodula } \\
\text { Inefektif } \\
\text { (Buah) } \\
\end{array}$ & $\begin{array}{c}\text { Diametet } \\
\text { Nodula Efektif } \\
\text { (mm) }\end{array}$ \\
\hline \multicolumn{3}{|l|}{ Dosis Inokulan B. Japonicum } \\
\hline $0 \mathrm{~g} \mathrm{~kg}^{-1}$ benih & $16.91 \mathrm{~b}$ & $3.99 \mathrm{a}$ \\
\hline $5 \mathrm{~g} \mathrm{~kg}^{-1}$ benih & $9.04 \mathrm{a}$ & $4.06 \mathrm{~b}$ \\
\hline $10 \mathrm{~g} \mathrm{~kg}^{1}$ benih & $18.90 \mathrm{~b}$ & $4.12 \mathrm{c}$ \\
\hline $15 \mathrm{~g} \mathrm{~kg}^{-1}$ benih & $18.04 \mathrm{~b}$ & $4.16 \mathrm{~d}$ \\
\hline \multicolumn{3}{|l|}{ Dosis Mikroba Pelarut Fosfat } \\
\hline $0 \mathrm{~kg} \mathrm{ha}^{-1}$ & $15.59 \mathrm{a}$ & $4.06 \mathrm{a}$ \\
\hline $50 \mathrm{~kg} \mathrm{ha}^{-1}$ & $11.73 \mathrm{a}$ & $4.09 \mathrm{~b}$ \\
\hline $100 \mathrm{~kg} \mathrm{ha}^{-1}$ & $17.59 \mathrm{a}$ & $4.09 \mathrm{bc}$ \\
\hline $150 \mathrm{~kg} \mathrm{ha}^{-1}$ & $17.18 \mathrm{a}$ & $4.10 \mathrm{c}$ \\
\hline
\end{tabular}

\section{Nisbah Pupus Akar (P/A)}

Hasil analisis ragam menunjukkan terdapat interaksi secara sinergis antara dosis inokulan pupuk hayati (B. japonicum) dan mikroba pelarut fosfat terhadap nisbah pupus akar $(p>0.05)$. Hasil perbandingan antar ratarata perlakuan dengan menggunakan Uji Jarak Berganda Duncan pada taraf nyata $5 \%$, dapat dilihat pada Tabel 3 .
Tabel 3 menunjukan bahwa inokulasi B. japonicum pada dosis $5 \mathrm{~g} \mathrm{~kg}^{-1}$ benih dan mikroba pelarut fosfat $50 \mathrm{~kg} \mathrm{ha}{ }^{-1}$ dapat meningkatkan jumlah nodula efektif hingga $110,23 \%$ dibanding dosis inokulasi $B$. japonicum pada dosis $0 \mathrm{~g} \mathrm{~kg}^{-1}$ benih dan mikroba pelarut fosfat $0 \mathrm{~kg} \mathrm{ha}^{-1}$.

Tabel 3. Pengaruh Pemberian Inokulan Pupuk Hayati (B. japonicum) dan Bio-fosfat terhadap Nisbah Pupus Akar (P/A).

\begin{tabular}{ccccc}
\hline Inokulan & \multicolumn{4}{c}{ Mikroba Pelarut Fosfat } \\
\cline { 2 - 5 } B. japonicum & $0 \mathrm{~kg} \mathrm{ha}^{-1}$ & $50 \mathrm{~kg} \mathrm{ha}^{-1}$ & $100 \mathrm{~kg} \mathrm{ha}^{-1}$ & $150 \mathrm{~kg} \mathrm{ha}^{-1}$ \\
\hline $0 \mathrm{~g} \mathrm{~kg}^{-1}$ benih & $23.88 \mathrm{a}$ & $25.07 \mathrm{ab}$ & $24.46 \mathrm{a}$ & $26.27 \mathrm{~b}$ \\
& $\mathrm{~A}$ & $\mathrm{~B}$ & $\mathrm{AB}$ & $\mathrm{B}$ \\
$5 \mathrm{~g} \mathrm{~kg}^{-1}$ benih & $24.30 \mathrm{a}$ & $27.28 \mathrm{~b}$ & $25.10 \mathrm{a}$ & $24.03 \mathrm{~b}$ \\
& $\mathrm{~A}$ & $\mathrm{~B}$ & $\mathrm{~A}$ & $\mathrm{~A}$ \\
$10 \mathrm{~g} \mathrm{~kg}^{1}$ benih & $26.33 \mathrm{a}$ & $23.12 \mathrm{a}$ & $24.22 \mathrm{a}$ & $21.37 \mathrm{a}$ \\
& $\mathrm{B}$ & $\mathrm{AB}$ & $\mathrm{B}$ & $\mathrm{A}$ \\
$15 \mathrm{~g} \mathrm{~kg}^{-1}$ benih & $24.34 \mathrm{a}$ & $26.02 \mathrm{ab}$ & $24.86 \mathrm{a}$ & $24.82 \mathrm{~b}$ \\
& $\mathrm{~A}$ & $\mathrm{~A}$ & $\mathrm{~A}$ & $\mathrm{~A}$ \\
\hline
\end{tabular}

Keterangan: $\quad$ Nilai rata-rata yang ditandai huruf kecil yang sama (arah vertikal) dan huruf kapital yang sama (arah horizontal) tidak berbeda nyata menurut Uji Jarak Berganda Duncan 5\%.

\section{Indeks Luas Daun}

Hasil analisis ragam menunjukkan tidak terdapat pengaruh interaksi secara sinergis antara inokulasi pupuk hayati (B. japonicum) dan mikroba pelarut fosfat terhadap indeks luas daun $(p<0.05)$. Inokulasi B. japonicum secara mandiri menunjukkan pengaruh nyata terhadap indeks luas daun. Inokulasi mikroba pelarut fosfat secara mandiri menunjukkan tidak terdapat pengaruh nyata terhadap terhadap 
indeks luas daun. Perbandingan antar rata-rata perlakuan dilakukan dengan menggunakan Uji
Jarak Berganda Duncan pada taraf nyata 5\% dan hasil analisis dapat dilihat pada Tabel 2.

Tabel 4. Pengaruh Pemberian Inokulan Pupuk Hayati (B. japonicum) dan Bio-fosfat terhadap Indeks Luas Daun.

\begin{tabular}{lc}
\hline \multicolumn{1}{c}{ Perlakuan } & Indeks Luas Daun \\
\hline Dosis Inokulan B. Japonicum & $1.43 \mathrm{a}$ \\
$0 \mathrm{~g} \mathrm{~kg}^{-1}$ benih & $1.64 \mathrm{~b}$ \\
$5 \mathrm{~g} \mathrm{~kg}^{-1}$ benih & $1.83 \mathrm{c}$ \\
$10 \mathrm{~g} \mathrm{~kg}^{1}$ benih & $1.87 \mathrm{c}$ \\
$15 \mathrm{~g} \mathrm{~kg}^{-1}$ benih & $1.63 \mathrm{a}$ \\
\hline Dosis Mikroba Pelarut Fosfat & $1.68 \mathrm{a}$ \\
$0 \mathrm{~kg} \mathrm{ha}^{-1}$ & $1.71 \mathrm{a}$ \\
$50 \mathrm{~kg} \mathrm{ha}^{-1}$ & $1.75 \mathrm{a}$ \\
$100 \mathrm{~kg} \mathrm{ha}^{-1}$ & \\
$150 \mathrm{~kg} \mathrm{ha}^{-1}$ &
\end{tabular}

Tabel 4 menunjukkan bahwa inokulasi B. japonicum pada dosis $5 \mathrm{~g} \mathrm{~kg}^{1}$ benih hingga $15 \mathrm{~g} \mathrm{~kg}^{1}$ benih dapat meningkatkan indeks luas daun.. Inokulasi mikroba pelarut fosfat pada dosis $50 \quad \mathrm{~kg}^{\mathrm{ha}} \mathrm{ha}^{-1}$ hingga $150 \mathrm{~kg} \mathrm{ha}^{-1}$ menunjukkan tidak dapat meningkatkan indeks luas daun dibanding dosis $0 \mathrm{~kg} \mathrm{ha}^{-1} \mathrm{~h}$.

Jumlah polong isi, Jumlah Polong Hampa, dan Bobot Polong per Tanaman

Hasil analisis ragam tidak menunjukkan pengaruh interaksi secara sinergis inokulasi $B$. japonicum dan mikroba pelarut fosfat terhadap jumlah polong isi, jumlah polong hampa, dan bobot polong per tanaman. Inokulasi $B$. japonicum secara mandiri menunjukkan pengaruh nyata terhadap jumlah polong isi dan bobot polong per tanaman, tetapi tidak nyata terhadap jumlah polong. Inokulasi Mikroba Pelarut Fosfat secara mandiri menunjukkan pengaruh tidak nyata terhadap jumlah polong isi dan bobot polong per tanaman, tetapi nyata terhadap jumlah polong hampa. Hasil perbandingan antar rata-rata perlakuan dengan menggunakan Uji Jarak Berganda Duncan pada taraf nyata 5\%, dapat dilihat pada Tabel 5 .

Tabel 5. Pengaruh Pemberian Inokulan Pupuk Hayati (B. japonicum) dan Bio-fosfat terhadap Jumlah Polong Isi dan Jumlah Polong Hampa

\begin{tabular}{lccc}
\hline \multicolumn{1}{c}{ Perlakuan } & $\begin{array}{c}\text { Jumlah Polong } \\
\text { Isi (Buah) }\end{array}$ & $\begin{array}{c}\text { Jumlah Polong } \\
\text { Hampa (Buah) }\end{array}$ & $\begin{array}{c}\text { Bobot Polong per } \\
\text { tanaman }(\mathrm{g})\end{array}$ \\
\hline Dosis Inokulan B. Japonicum & & & \\
$0 \mathrm{~g} \mathrm{~kg}^{-1}$ benih & $92.91 \mathrm{a}$ & $2.57 \mathrm{a}$ & $32.79 \mathrm{a}$ \\
$5 \mathrm{~g} \mathrm{~kg}^{-1}$ benih & $107.82 \mathrm{~b}$ & $2.48 \mathrm{a}$ & $38.43 \mathrm{~b}$ \\
$10 \mathrm{~g} \mathrm{~kg}^{-1}$ benih & $110.00 \mathrm{~b}$ & $2.45 \mathrm{a}$ & $38.30 \mathrm{~b}$ \\
$15 \mathrm{~g} \mathrm{~kg}^{-1}$ benih & $109.75 \mathrm{~b}$ & $2.47 \mathrm{a}$ & $39.85 \mathrm{~b}$ \\
\hline Dosis Mikroba Pelarut Fosfat $_{0 \mathrm{~kg} \mathrm{ha}^{-1}}$ & $102.84 \mathrm{a}$ & $2.83 \mathrm{~b}$ & $36.47 \mathrm{a}$ \\
$50 \mathrm{~kg} \mathrm{ha}^{-1}$ & $104.27 \mathrm{a}$ & $2.58 \mathrm{ab}$ & $38.14 \mathrm{a}$ \\
$100 \mathrm{~kg} \mathrm{ha}^{-1}$ & $106.97 \mathrm{a}$ & $2.37 \mathrm{ab}$ & $38.17 \mathrm{a}$ \\
$150 \mathrm{~kg} \mathrm{ha}^{-1}$ & $106.41 \mathrm{a}$ & $2.18 \mathrm{a}$ & $36.59 \mathrm{a}$ \\
\hline Keterangan: Nilai rata-rata yang diikuti oleh huruf yang sama tidak berbeda nyata Menurut Uji Jarak \\
\multicolumn{2}{c}{ Berganda Duncan pada taraf 5\%. }
\end{tabular}


Tabel 5 menunjukkan bahwa bahwa inokulasi B. japonicum pada dosis $5 \mathrm{~g} \mathrm{~kg}^{1}$ benih hingga $15 \mathrm{~g} \mathrm{~kg}^{1}$ benih dapat meningkatkan jumlah polong isi dan bobot polong, tetapi tidak menurunkan jumlah polong hampa per tanaman dibanding $0 \mathrm{~g} \mathrm{~kg}^{1}$ benih. Inokulasi mikroba pelarut fosfat pada dosis $50 \mathrm{~kg} \mathrm{ha}^{-1}$ hingga $150 \mathrm{~kg} \mathrm{ha}^{-1}$ tidak dapat meningkatkan jumlah polong isi dan bobot polong, tetapi dapat menurunkan jumlah polong hampa per tanaman dibanding dosis dosis $0 \mathrm{~kg} \mathrm{ha}^{-1}$.

Bobot 100 biji, Bobot Biji per Tanaman, dan Bobot Biji per Petak
Hasil analisis ragam tidak menunjukkan pengaruh interaksi secara sinergis antara inokulasi B. japonicum dan Mikroba Pelarut Fosfat terhadap bobot 100 biji, bobot biji per tanaman dan bobot biji per petak. Inokulasi $B$. japonicum secara mandiri menunjukkan pengaruh nyata terhadap bobot 100 biji, bobot biji per tanaman dan bobot biji per petak. Inokuilasi mikroba pelarut fosfat secara mandiri menunjukkan pengaruh tidak nyata terhadap bobot 100 biji, bobot biji per tanaman dan bobot biji per petak. Hasil perbandingan antar rata-rata perlakuan dengan menggunakan Uji Jarak Berganda Duncan pada taraf nyata 5\%, dapat dilihat pada Tabel 6 .

Tabel 6. Pengaruh Pemberian Inokulan Pupuk Hayati (B. japonicum) dan Bio-fosfat terhadap Bobot 100 biji, Bobot Biji per Tanaman dan Bobot Biji per Petak

\begin{tabular}{lccc}
\hline \multicolumn{1}{c}{ Perlakuan } & Bobot 100 Biji & $\begin{array}{c}\text { Bobot Biji per } \\
\text { Tanaman }(\mathrm{g})\end{array}$ & $\begin{array}{c}\text { Bobot Biji per } \\
\text { Petak }(\mathrm{kg})\end{array}$ \\
\hline Dosis Inokulan B. Japonicum & $13.51 \mathrm{a}$ & $24.88 \mathrm{a}$ & $2.59 \mathrm{a}$ \\
$0 \mathrm{~g} \mathrm{~kg}^{-1}$ benih & $13.72 \mathrm{ab}$ & $29.16 \mathrm{~b}$ & $3.03 \mathrm{~b}$ \\
$5 \mathrm{~g} \mathrm{~kg}^{-1}$ benih & $13.90 \mathrm{ab}$ & $29.05 \mathrm{~b}$ & $3.02 \mathrm{~b}$ \\
$10 \mathrm{~g} \mathrm{~kg}^{-1}$ benih & $14.30 \mathrm{~b}$ & $30.23 \mathrm{~b}$ & $3.14 \mathrm{~b}$ \\
$15 \mathrm{~g} \mathrm{~kg}^{-1}$ benih & & & \\
\hline Dosis Mikroba Pelarut Fosfat & $13.57 \mathrm{a}$ & $27.67 \mathrm{a}$ & $2.88 \mathrm{a}$ \\
$0 \mathrm{~kg} \mathrm{ha}^{-1}$ & $14.09 \mathrm{a}$ & $28.93 \mathrm{a}$ & $3.01 \mathrm{a}$ \\
$50 \mathrm{~kg} \mathrm{ha}^{-1}$ & $13.96 \mathrm{a}$ & $28.96 \mathrm{a}$ & $3.01 \mathrm{a}$ \\
$100 \mathrm{~kg} \mathrm{ha}^{-1}$ & $13.82 \mathrm{a}$ & $27.76 \mathrm{a}$ & $2.89 \mathrm{a}$ \\
$150 \mathrm{~kg} \mathrm{ha}^{-1}$ & & &
\end{tabular}

Jarak Berganda Duncan pada taraf 5\%.

Tabel 6 menunjukkan bahwa bahwa inokulasi B. japonicum pada dosis $5 \mathrm{~g} \mathrm{~kg}^{1}$ benih hingga $15 \mathrm{~g} \mathrm{~kg}^{1}$ benih dapat meningkatkan bobot 100 biji, bobot biji per tanaman, dan bobot biji per petak dibanding dosis $0 \mathrm{~g} \mathrm{~kg}^{1}$ benih. Inokulasi mikroba pelarut fosfat pada dosis $50 \mathrm{~kg} \mathrm{ha}^{-1}$ hingga $150 \mathrm{~kg} \mathrm{ha}^{-1}$ tidak dapat meningkatkan bobot 100 biji, bobot biji per tanaman, dan bobot biji per petak dibanding dosis $0 \mathrm{~g} \mathrm{~kg}^{1}$ benih.

\section{Pembahasan}

Inokulasi B. japonicum pada dosis $5 \mathrm{~g} \mathrm{~kg}$ ${ }^{1}$ benih dan mikroba pelarut fosfat $50 \mathrm{~kg} \mathrm{ha}^{-1}$ secara sinergis dapat meningkatkan jumlah nodula efektif sebesar $110,48 \%$ dan nisbah pupus akar sebesar 13,83\%. Secara mandiri dosis Inokulasi $B$. japonicum $5 \mathrm{~g} \mathrm{~kg}^{-1}$ benih menurunkan jumlah nodula tidak efektif sebesar 46,54\%, meningkatkan diameter nodula efektif sebesar $1,75 \%$,

Inokulasi $B$. japonicum meningkatkan populasi B. japonicum yang efektif dalam jumlah optimum, sehingga dapat berkembangbiak, membentuk koloni dan mendominasi daerah perakaran tanaman kedelai, sehingga mampu bersaing dengan strain $B$. japonicum indigenous. Kehadiran $B$. japonicum merangsang tanaman kedelai untuk mensekresikan senyawa flavonoid ke rizosfer (Hubber et al., 2006), kemudian B. japonicum menanggapinya dengan mensekresikan lipochitooligosaccharide yang dikenal sebagai nod faktor (Ferguson, 2010). Nod faktor menginduksi proses pembentukan dan deformasi rambut akar, pembentukan primordia nodula akar dan memainkan peran kunci selama inisiasi nodula akar (D'Haeze dan 
Holsters, 2002), sehingga terbentuk sejumlah nodula akar yang efektif dan dengan demikian menurunkan jumlah nodula akar yang tidak efektif.

Pada saat yang sama, tanaman kedelai juga harus memperoleh hara $\mathrm{P}$ dari tanah, karena hampir setiap aspek dari simbiosis antara akar tanaman kedelai dan B. japonicum dipengaruhi dan akhirnya dibatasi oleh ketersediaan hara P. Nodula akar tanaman kedelai merupakan pemanfaat hara $\mathrm{P}$, dan memiliki kapasitas yang kuat untuk mengambil $\mathrm{P}$ dari dalam tanah. Hasil penelitian menunjukkan bahwa pertukaran antara senyawa karbon hasil fotosintesis tanaman inang dan bakteroid terdapat aliran bersih $\mathrm{P}$ yang keluar dari nodula akar untuk melengkapi siklus hidupnya (McDermott, 2004).

Inokulasi mikroba pelarut fosfat meningkatkan kadar $\mathrm{P}$ larut dalam tanah melalui mekanisme pelarutan fosfat secara kimia yang dilakukan oleh mikroorganisme pelarutan fosfat (P. fluorescen, Bacillus Sp. dan A. niger). Mikroorganisme tersebut menseksresikan sejumlah asam organik berbobot molekul rendah seperti oksalat, suksinat tartrat, sitrat laktat, $\alpha$-ketoglutarat, asetat, formiat, glikolat, glutamat, glioksilat, malat, fumarat, selanjutnya asam-asam organik ini bereaksi dengan bahan pengikat fosfat membentuk khelat organik yang stabil sehingga mampu membebaskan ion fosfat terikat (Santosa, 2007). Fosfor berperan penting dalam meningkatkan inisiasi pembentukan dan pengembangan fungsi nodula akar (Shu-Jie et al. 2007; Abbasi et al., 2008; Waluyo et al., 2004; Khan et al., 2009), namun perannya dalam proses itu tetap masih belum jelas (Tsvetkova, 2003).

Inokulasi B. japonicum pada dosis $5 \mathrm{~g}$ $\mathrm{kg}^{-1}$ benih dan mikroba pelarut fosfat $50 \mathrm{~kg} \mathrm{ha}$ 1 secara sinergis meningkatkan ketersediaan hara $\mathrm{N}$ dan $\mathrm{P}$ secara optimal yang mempengaruhi "keseimbangan fungsional" dalam partisi bahan kering antara tajuk dan akar. Pada tanaman kedelai yang bergantung pada $\mathrm{N}$ simbiosis, translokasi fotosintat ke tanaman bagian bawah digunakan untuk pertumbuhan dan fungsi nodula dan akar selama fase pertumbuhan vegetatif, sehingga meningkatkan jumlah nodula efektif dan bobot akar yang akhirnya mempengaruhi nisbah pupus akar.

Dosis Inokulasi B. japonicum $5 \mathrm{~g} \mathrm{~kg}^{-1}$ benih meningkatkan indek luas daun sebesar
14,69\%, meningkatkan jumlah polong sebesar $16,04 \%$, menurunkan jumlah polong hampa sebesar 3,62\%, meningkatkan bobot polong per tanaman sebesar $17,20 \%$, meningkatkan bobot 100 biji sebesar $1,55 \%$, meningkatkan bobot biji per tanaman sebesar $17,20 \%$, dan meningkatkan bobot bibi per petak sebesar 16,99\%. Dosis $150 \mathrm{~kg} \mathrm{ha}^{-1}$ dapat meningkatkan diameter nodula efektif hingga $0,98 \%$ dan menurunkan jumlah polong hampa 29,82\%.Peningkatan ini berkaitan dengan ketersediaan $\mathrm{N}$ bagi tanaman yang dihasilkan melalui fiksasi $\mathrm{N}_{2}$ dari udara oleh $B$ japonicum. Ureides merupakan hasil akhir dari fiksasi $\mathrm{N}_{2}$ dari udara oleh $B$ japonicum yang ditranslokasikan ke tajuk (White et al., 2007) dan dialokasikan pada organ-organ vegetatif sebelum fase pengisian biji (Schulz et al., 2005), termasuk pada daun. Menurut Hikosaka (2003) bahwa luas daun bertambah, karena pertumbuhan daun baru yang ditunjang oleh fotosintesis, dan kapasitas fotosintesis ditentukan oleh distribusi cahaya dan nitrogen daun.

Polong yang tumbuh menggunakan sejumlah besar nitrogen dan karbon (Fischinger dan Schulze, 2010). Serapan N, asimilasi C dan alokasi keduanya antar organ memainkan peran tertentu dan asimilasi $\mathrm{C}$ terkait dengan distribusi $\mathrm{N}$ pada daun dan organ fotosintesis lainnya, serta proses fotosintesis secara keseluruhan (Gastal, 2002). Tanaman kedelai yang bergantung pada $\mathrm{N}$ simbiosis, pasokan $\mathrm{C}$ selama pengisian biji sebagian besar bergantung pada fotosintesis secara langsung, sedangkan pasokan $\mathrm{N}$ selama pengisian biji, diperoleh dari remobilisasi $\mathrm{N}$ dari organ vegetatif (daun, dinding polong, batang) (Schulz et al., 2005) dan/atau dari nodula akar (Fischinger dan Schulze, 2010).

Menurut Dubbs (2000) pengembangan biji merupakan sink yang kuat, bergantung pada produk penyimpanan dan remobilisasi asimilasi karbon dan nitrogen untuk memasok nutrisi yang dibutuhkan untuk pematangan biji. Namun, remobilisation $\mathrm{N}$ dari jaringan vegetatif dapat menurunkan kapasitas fotosintesis karena mempercepat senescen daun, yang akhirnya memperpendek periode pengisian biji. Oleh karena itu, untuk mengoptimalkan pengisian biji tanpa mengurangi kuantitas dan kualitas biji yang dihasilkan perlu mengurangi ketergantungan pada $\mathrm{N}$ remobilisasi dengan meningkatkan pasokan $\mathrm{N}$ yang diantaranya dengan 
memperpanjang aktivitas fiksasi $\mathrm{N}_{2}$ simbiosis (Salon, 2001).

Menurut Fischinger dan Schulze (2010) pada pembentukan dan pengisian polong, fiksasi $\mathrm{N}_{2}$ tanaman lebih tinggi dibandingkan pertumbuhan vegetatif dan aktivitas nodula akar pun meningkat kurang lebih $25 \%$. sehingga polong tumbuh dengan cepat dan memiliki jaringan yang mengandung $\mathrm{N}$ yang tinggi. Hal ini akan berdampak pada meningkatnya jumlah polong isi dan bobot polong. Bobot polong akan berkorelasi positif dengan peningkatan bobot biji.

\section{KESIMPULAN}

Dapat disimpulkan bahwa adanya interaksi antara inokulasi $B$. japonicum dengan mikroba pelarut phospate, dan dosis $150 \mathrm{~kg} \mathrm{ha}^{-1}$ mampu menghasilkan pertumbuhan dan hasil yang lebih baik.

\section{SARAN}

Upaya meningkatkan produksi kedelai disarankan untuk melakukan inokulasi $B$. japonicum pada benih sebelum di tanam dengan dosis $5 \mathrm{~g} \mathrm{~kg}^{-1}$ benih.

\section{DAFTAR PUSTAKA}

D'HAEZE W, HOLSTERS M. 2002. Nod factor structures, responses, and perception during initiation of nodule development. Glycobiology. Jun;12(6):79R-105R. doi: 10.1093/glycob/12.6.79r. PMID: 12107077.

DUBBS, W. E., \& GRIMES, H. D. (2000). The mid-pericarp cell layer in soybean pod walls is a multicellular compartment enriched in specific lipoxygenase isoforms. Plant physiology, 123(4), 1281-1288. https://doi.org/10.1104/pp.123.4.1281.

FISCHINGER， S. A. AND SCHULZE, J. 2010. The importance of nodule $\mathrm{CO} 2$ fixation for the efficiency of symbiotic nitrogen fixation in pea at vegetative growth and during pod formation .Journal of Experimental Botany, Page 1 of 11 .

GASTAL, F. AND LEMAIRE, G. 2002. N uptake and distribution in crops: an agronomical and ecophysiological perspective. J. Exp. Bot. 53 (370): 789799.
HIKOSAKA, K AND NIELS P. R. ANTEN. 2012. An evolutionary game of leaf dynamics and its consequences for canopy structure. Funcional ecology. Volume26, Issue 5. October 2012. https://doi.org/10.1111/j.13652435.2012.02042.x

HUBBER, A. M., SULliVAN, J.T., DAN RONSON C.W. 2006. SymbiosisInduced Cascade Regulation of the Mesorhizobium loti R7A VirB/D4 Type IV Secretion System. MPMI Vol. 20, No. 3, pp. 255-261.

ISHERWORD, K. F. 1998. Fertilizer use and environment. In: N. Ahmed and A. Hamid (eds.), Proc. Symp. Plant Nutrition Management for Sustainable Agricultural Growth. NFDC, Islamabad. pp. 57-76.

KHAN, A.A., JILANI, G., AKHTAR, M.S., NAQVI, S.M.S, RASEED, M. 2009. Phosphorus Solubilizing Bacteria: Occurrence, Mechanisms and their Role in Crop Production. J. Agric. Biol. SCI. 1(1): 48-58.

Mc. DERMOTT, T. R. DAN GRAHAM, P.H. 1989. Bradyrhizobium japonicum Inoculant Mobility, Nodule Occupancy, and Acetylene Reduction in the Soybean Root System. Appl Environ Microbiol. 55(10): 2493-2498.

NIELSEN, R. L. 2006. N Loss Mechanisms and Nitrogen Use Efficiency. Purdue Nitrogen Management Workshops, Purdue University.

RAUN, W. R. DAN JOHNSON, G. V. 1999. Improving Nitrogen Use Efficiency for Cereal Production. Review dan Interpretation. Agronomy Journal, Volume 91:357-363.

SANTOSA, E. 2007. Mikroba Pelarut Fosfat. Dalam Saraswati, R., Husen, E., dan Simanungkalit, R.D.M. Metode Analisis Biologi Tanah. Selected reading, hlm. 55-68. Balai Besar Litbang Sumbrdaya Lahan Pertanian. Badan Penelitian dan Pengembangan Pertanian. Deptan.

SALON,C. NATHALIE G. MUNIERJOLAIN, GÉRARD DUC, ANNESOPHIE VOISIN, DAVID GRANDGIRARD, et al.. 2001 Grain legume seed filling in relation to nitrogen acquisition: A review and prospects with particular reference to pea. Agronomie, 
EDP Sciences, , 21 (6-7), pp.539-552. ff10.1051/agro:2001143ff.

SCHULZ, T.J., THELEN, K.D., AND WANG, D. 2005. Effect of Bradyrhizobium japonicum Inoculant on Soybean Growth and Yield. Michigan State University, Crop and Soil Science Department

SINGH T. DAN PUROHIT, S.S. 2011. Biofertilizer Technology. Agrobios (India).

SHU-JIE, M., YUN-FA, Q., XIAO-ZENG, H.. 2007. Nodule Formation and Development in Soybeans (Glycine max L.) in Response to Phosphorus Supply in Solution Culture. Pedosphere 17(1):3643.

TSVETKOVA, G. \& GEORGIEV, G. 2003. Growth, Nodulation and Dinitrogen Fixation Related to the Changes of Phosphate Fractions of Nodules and Leaves of Phosphorus Starved Soybean (Glycine max L. Merr.) Plants. Comptes Rendus de l'Academie Bulgare des Sciences, vol.56, p.9:47

VANCE C.P. 2001. Symbiotic Nitrogen Fixation and Phosphorus Acquisition. Plant Nutrition in a World of Declining Renewable Resources. Plant Physiology vol. 127 no. 2 390-397.

WALUYO S.H, LIEB T. A. DAN MANNETJE L. 2004. Effect of Phosphate on Nodule Primordia of Soybean (Glycine max (L.) Merrill) in Acid Soils in Rhizotron experiments Indonesian of soybean 37-44.

WASULE, D., WADYALKAR S. AND BULDEO, A., 2007. Effect of phosphate solubilizing bacteria on role of Rhizobium on nodulation by soybean. First International Meeting on Microbial Phosphate Solubilization Developments in Plant and Soil Sciences, Volume 102, 139-142, DOI: 10.1007/978-14020-5765-6-20.

ZAREI, I., SOHRABI1, Y., HEIDARI1, G.R., JALILIAN, A. AND MOHAMMADI, K. 2012. Effects of biofertilizers on grain yield and protein content of two soybean (Glycine $\max$ L.) cultivars. African Journal of Biotechnology Vol. 11(27), pp. 7028-7037. 